\title{
KONFLIK PERAN GANDA TERHADAP TINGKAT STRESS KERJA POLISI WANITA DI POLRES LAMPUNG UTARA
}

\author{
Sulastri*, Almurhan* \\ *Jurusan Keperawatan Poltekkes Tanjungkarang \\ Email: sulastri@poltekkes-tjk.ac.id
}

\begin{abstract}
Anggota kepolisian terutama polisi wanita memiliki pekerjaan yang stressful, karena dalam penugasannya tidak memiliki kontrol yang diberikan kepadanya dan sulitnya menghadapi pelaku kejahatan. Sumber stres yang diasosiasikan dengan pekerjaan polisi adalah bahaya dalam pekerjaan, sepertiv kematian rekan kerja saat bertugas atau situasi kerja yang mengacam dimana polisi terpaksa mengambil nyawa seseorang. Tujuan penelitian ini untuk menganalisis hubungan konflik peran ganda dengan tingkat stress kerja pada polisi wanita di Lampung Utara. Penelitian ini menggunakan pendekatan kuantitatif, metode yang digunakan adalah rancangan cross sectional. Populasi dalam penelitian ini adalah semua polisi wanita yang bekerja di kedinasan Polres Kotabumi Lampung Utara berjumlah 42 orang dengan jumlah sampel 36 responden ditentukan dengan purposive sampling. Pengukuran data dengan anket kinerja dan stress kerja pada polisi wanita. Hasil analisis univariat diketahui sebagian besar responden mengalami konflik peran ganda, yaitu 31 orang $(86,1 \%)$ dan stress kerja pada tingkat yang sedang sebanyak 28 orang $(77,8 \%)$. Hasil analisis bivariat dilakukan menggunakan uji chi-square diperoleh p-value 0,001 ( $\mathrm{p}<0,005)$. Hasil ini menunjukkan ada hubungan konflik peran ganda dengan tingkat stress kerja pada polisi wanita di Polres Lampung Utara. Disarankan untuk tenaga kesehatan agar dapat melakukan edukasi terkait tentang peran kepada keluarga, serta edukasi tentang pencegahan dan pengendalian terhadap stres kerja yang nantinya dapat berpengaruh terhadap kemutuan kinerja.
\end{abstract}

Kata Kunci: konflik, peran ganda, stress kerja

\section{LATAR BELAKANG}

Sebagai seorang abdi negara polisi bertugas menjaga keamanan negara, mengatur ketertiban dan juga menegakkan hukum.Menjalankan tugas-tugas kepolisian tidaklah semudah yang dibayangkan. Seorang polisi tidak cukup hanya mengandalkan kondisi fisik yang baik saja, tetapi juga kecerdasan dan keterampilan. Seorang polisi harus cekatan, seorang polisi harus selalu siap di segala kondisi. Termasuk dalam keadaan darurat yang bisa mengancam keselamatan jiwa. Tuntutan tugas sebagai polisi tidak hanya merupakan kewajiban polisi pria, tetapi juga berlaku pada wanita. Peran seorang wanita cukup komplek. Wanita yang bekerja tidak serta merta meninggalkan tugasnya dirumah. Sudah menjadi kodrat wanita untuk bertanggungjawab terhadap urusan rumah tangga, khususnya wanita yang sudah berkeluarga. Wanita karir khususnya yang sudah berkeluarga akan memikul dua peran yang berbeda yaitu peran pekerjaan dan peran keluarga yang akan memperberat kondisi stress kerja dan juga mempengaruhi kinerja yang dimiliki ketika wanita karir tidak dapat menyeimbangkan antara dua peran tersebut maka akan mengalami konflik (Laksmi, 2012).

Para wanita yang bekerja dikabarkan sebagai pihak yang mengalami stress lebih tinggi dibandingkan dengan pria. Masalahnya, wanita bekerja ini menghadapi konflik peran sebagai wanita karir sekaligus ibu rumah tangga. Stress yang dimaksud disini adalah stress yang menyebabkan ketegangan/penderitaan psikis sehingga menimbulkan kecemasan (Rini, JF, 2002).

Azwar, S (1999). Menyatakan bahwa dalam ilmu psikologi, stress merupakan tekanan atau tuntutan pada organisme untuk beradaptasi atau menyelaraskan diri dengan lingkungan sehingga memiliki efek fisik dan psikis serta dapat membuat perasaan positif atau negatif. Sedangkan tingkat stres adalah hasil penilaian terhadap berat ringannya stress yang dialami seseorang. Tingkatan stress ini diukur dengan menggunakan Depression Anxiety Stress Scale 42 (DASS 42). Tingkatan stress pada instrumen ini 
berupa normal, rendah, sedang, berat, dan sangat berat (Hidayati, F, 2000).

Menrut Wanita karir adalah wanita yang mempergunakan waktunya untuk bekerja baik di dalam rumah maupun di luar rumah dengan tujuan untuk memperoleh pendapatan yang akan dipergunakan bagi kebutuhan keluarga (Endar, 2008, dalam Nova, 2012). Sedangkan faktor-faktor yang diduga mempengaruhi tingkat stress wanita karir yang disebabkan konflik peran gandanya dikelompokan menjadi 7 aspek yaitu: faktor pengasuhan anak, faktor bantuan pekerjaan rumah tangga, faktor komunikasi dan interaksi dengan anak dan suami, faktor waktu untuk keluarga, faktor penentuan prioritas, faktor tekanan karir dan tekanan keluarga, serta faktor pandangan suami terhadap peran ganda wanita. Ke tujuh aspek tersebut diduga mempengaruhi tingkat stress wanita karir dalam peran gandanya (Azwar, 1999).

Konflik peran dan stress yang terjadi pada polisi wanita sebagai seorang abdi negara bertugas menjaga keamanan negara, mengatur ketertiban dan juga menegakkan hukum. Menjalankan tugas-tugas kepolisian tidaklah semudah yang dibayangkan. Seorang polisi tidak cukup hanya mengandalkan kondisi fisik yang baik saja, tetapi juga kecerdasan dan keterampilan. Seorang polisi harus cekatan, seorang polisi harus selalu siap di segala kondisi. Termasuk dalam keadaan darurat yang bisa mengancam keselamatan jiwa. Tuntutan tugas sebagai polisi tidak hanya merupakan kewajiban polisi pria, tetapi juga berlaku pada wanita.

Penelitian mengenai prevalensi stres kerja pada anggota kepolisian, menunjukkan prevalensi stres pada anggota polisi adalah sekitar $31,2 \%$. Sementara itu, tiga penelitian yang dilakukan di Asia menunjukkan hasil sebagai berikut: di Pakistan adalah 30,84\%, Di Thailand, 61,4\% ,Di Malaysia 41,9\% (Sherina, 2017).

Penelitian tentang stres pada anggota kepolisian juga pernah dilakukan di Indonesia yaitu di Polres Bangka didapatkan gambaran tingkat stres pada anggota kepolisian sebesar $71 \%$. Secara keseluruhan, prevalensi stres pada anggota kepolisian yaitu berkisar $30-70 \%$, dan sekitar $46.3 \%$ anggota polisi yang mengalami stress adalah anggota polisi wanita (Abdulghani, 2017).

Penelitian tentang stres pada anggota kepolisian juga pernah dilakukan di Indonesia yaitu di Polres Bangka didapatkan gambaran tingkat stres pada anggota kepolisian sebesar 71\%. Secara keseluruhan, prevalensi stres pada anggota kepolisian yaitu berkisar 30-70\%, dan sekitar $46.3 \%$ anggota polisi yang mengalami stress adalah anggota polisi wanita (Abdulghani, 2017).

Salah satu penyebab terjadinya stress kerja pada polisi wanita adalah konflik peran ganda. Menjadi seorang polisi wanita akan mengakibatkan terjadinya konflik peran dimana kondrat seorang wanita merupakan sebagai pengurus rumah tangga, anak dan suami dimana akan terjadi ketidak sesuaian dengan tugas rumah tangga seorang wanita. Seorang polwan dalam menyelesaikan tugastugas dalam pekerjaannya terdapat gangguan atau masalah-masalah yang berhubungan dengan faktor psikologis, misalnya wanita itu merasa bersalah telah meninggalkan keluarganya untuk bekerja, tertekan karena terbatasnya waktu dan beban pekerjaan terlalu banyak serta situasi kerja yang kurang menyenangkan. Keadaan ini akan mengganggu pikiran dan mental polwan ketika bekerja yang beraibat pada terjadinya stress kerja dan akan mempengaruhi kinerja pada polisi wanita (Gibson, 2005).

Anggota kepolisian terutama polisi wanita memiliki pekerjaan yang stressful, karena dalam penugasannya tidak memiliki kontrol yang diberikan kepadanya dan sulitnya menghadapi pelaku kejahatan. Sumber stres yang diasosiasikan dengan pekerjaan polisi adalah bahaya dalam pekerjaan, sebagai contoh kematian rekan kerja saat bertugas, situasi kerja yang mengacam dimana polisi terpaksa mengambil nyawa seseorang, situasi penangkapan pelaku kejahatan yang mengancam nyawa polisi, serta adeganadegan krimilitas yang membahayakan (Magdalena 2009).

Wilayah hukum Polres Lampung Utara merupakan tempat yang memiliki angka kriminalitas tertinggi di provinsi Lampung. Berdasarkan data hasil evaluasi tingkat kriminalitas selama tiga bulan terakhir pada 
tahun 2018 di wilayah Polda Lampung sudah terjadi 127 kasus kriminalitas, dimana Lampung Utara menempati posisi teratas tindak kriminalitas tertinggi, yakni 50 kasus.

\section{METODE}

Penelitian ini menggunakan desain penelitian analitik untuk mengetahui hubungan konflik peran ganda dengan stress kerja, dengan menggunakan pendekatatan cross sectional.

Sampel dalam penelitian ini adalah semua polisi wanita di kedinasan Polres Kotabumi Lampung Utara yang sudah menikah yang bekerja sebanyak 36 orang.

Data dikumpulkan dengan menggunakan angket yang diisi langsung oleh responden. Analisis bivariat dalam penelitian ini di gunakan untuk menggambarkan hubungan konflik peran ganda dengan stress kerja polwan menggunakan uji chi square dengan keputusan uji, jika nilai $p$ value $<\alpha(0,05)$ maka terdapat hubungan yang signifikan antara kedua variabel dan Ho di tolak.

\section{HASIL}

\section{Analsis Univariat}

Tabel 1: Distribusi Frekuensi Konflik Peran Ganda

\begin{tabular}{lcc}
\hline \multicolumn{1}{c}{ Konflik Peran Ganda } & $\mathrm{f}$ & $\%$ \\
\hline Mengalami & 31 & 86.1 \\
\hline Tidak Mengalami & 5 & 13.9 \\
\hline Jumlah & 36 & 100,0 \\
\hline
\end{tabular}

Tabel di atas menggambarkan bahwa sebagian besar responden mengalami konflik peran ganda $(86,1 \%)$.
Tabel 2: Distribusi Frekuensi Stress Kerja

\begin{tabular}{lcc}
\hline \multicolumn{1}{c}{ Stres Kerja } & f & $\%$ \\
\hline Stres Sedang & 28 & 77,8 \\
\hline Stres Ringan & 8 & 22,2 \\
\hline Jumlah & 36 & 100 \\
\hline
\end{tabular}

Tabel di atas mengambarkan bahwa sebagian besar responden mengalami stress kerja pada tingkat sedang $(77,8 \%)$.

\section{Analisis Bivariat}

Tabel 3: Hubungan Konflik Peran Ganda dengan Stres Kerja pada Polisi Wanita

\begin{tabular}{lccccccc}
\hline \multirow{2}{*}{$\begin{array}{l}\text { Konflik Peran } \\
\text { Ganda }\end{array}$} & \multicolumn{4}{c}{$\begin{array}{c}\text { Stres } \\
\text { sedang }\end{array}$} & \multicolumn{2}{c}{$\begin{array}{c}\text { Stres } \\
\text { ringan }\end{array}$} & \multirow{2}{*}{ Total } \\
\cline { 2 - 6 } & $\mathrm{f}$ & $\%$ & $\mathrm{f}$ & $\%$ & $\mathrm{f}$ & $\%$ \\
\hline Mengalami & 25 & 80.6 & 6 & 19,4 & 31 & 86.1 \\
\hline $\begin{array}{l}\text { Tidak } \\
\text { Mengalami }\end{array}$ & 3 & 60 & 2 & 40 & 5 & 13.9 \\
\hline Jumlah & 28 & 77,8 & 8 & 22,2 & 36 & 100 \\
\hline$p$ value & 0.001 & & & & \\
\hline
\end{tabular}

Tabel di atas menggambarkan bahwa diantara responden yang mengalami konflik peran ganda terdapat $80,6 \%$ yang mengalami stres sedang dan yang tidak mengalami konflik peran ganda terdapat $60 \%$ yang mengalami stres sedang. Hasil uji statistik diperoleh nilai $p$ value $=0,001$, dengan demikian ada hubungan yang antara konflik peran ganda dengan stres kerja.

\section{PEMBAHASAN}

Berdasarkan analisis univariat diketahui bahwa responden paling banyak adalah mengalami peran ganda yaitu sebanyak 31 responden $(86,1 \%)$. Hasil ini sejalan dengan hasil penelitian yang dilakukan oleh Markuawati, Rahardjo, \& Setyowati, (2015), bahwa ada hubungan dengan arah hubungan yang positif menunjukan bahwa semakin tinggi konflik peran ganda maka semakin tinggi stres kerja. Sumbangan efektif konflik peran ganda terhadap stres kerja sebesar 39,7 \%. Hasil penelitian ini menunjukkan bahwa hipótesis 
yang di ajukan diterima yaitu ada pengaruh konflik peran ganda terhadap stres kerja.

Konflik yang dialami wanita yang sudah menikah juga dihadapkan pada peran domestik nya sebagai istri dan ibu dalam rumah tangga. Hal ini tentunya menjadi tantangan tersendiri, karena apabila tidak dapat dikelola dengan baik, bisa mempengaruhi kinerja atau bahkan keutuhan keluarga. Amran dalam Achmad Sudiro (2003, dalam Jeni, 2015) mengatakan bahwa secara umum resiko yang akan dihadapi perempuan yang berkarir adalah: terabaikannya keluarga, terkurasnya tenaga dan pikiran, sulitnya menghadapi konflik peran antara kedudukan sebagai ibu rumah tangga dan sebagai wanita karir, timbulnya stres dan beban pikiran, dan berkurangnya waktu untuk diri sendiri.

Perempuan berkarir sering dihadapkan pada perasaan bersalah atas terabaikannya keluarga karena karir yang dijalaninya. Namun begitu, ada beberapa alasan yang membuat perempuan tetap pada pilihan karirnya walaupun dihadapkan pada resiko yang berat, antara lain karena ingin mandiri secara finansial sehingga lepas dari ketergantungan pada suami, ingin mengaplikasikan ilmu dan keterampilan yang diperoleh di tempat pendidikan ke dalam dunia kerja, ingin memperoleh status terhormat dalam masyarakat, serta ingin memperoleh pengakuan dari lingkungan bahwa seorang perempuan mampu berkarya dan berprestasi. (Pangastuti, 2001, dalam Jeni, 2015).

Kondisi perempuan dengan peran ganda sebagai pekerja dan sekaligus istri serta ibu dalam rumah tangga ini tentunya tidak jarang dapat menjadi beban tersendiri. Tuntutan pekerjaan mengharuskan seorang individu untuk dapat menyelesaikan tanggung jawabnya dengan sebaik mungkin, namun jika kapasitas individu tersebut tidak sesuai dengan beban kerja yang diberikan kepadanya, maka individu tersebut dapat mengalami tekanan atau biasa yang disebut dengan stres kerja. Stres kerja bisa disebabkan banyak faktor, antara lain yang berasal dari internal individu itu sendiri, seperti konflik peran pada diri individu tersebut; dari keluarga, misalnya kurangnya dukungan yang diberikan oleh keluarga seperti dukungan suami kepada istrinya; dan juga berasal dari lingkungan kerja atau lingkungan tempat tinggal yang tidak nyaman (Hardjana, 1994, dalam Jeni, 2015).

Konflik peran muncul akibat tidak konsistennya antara mekanisme kontrol birokrasi dengan prinsip, etika, kemandirian profesional dan norma, pengharapan yang sulit untuk dipenuhi atau dipuaskan. Stres kerja dan menurunnya kepuasan kerja merupakan beberapa dampak yang disebabkan oleh konflik peran. Selain konflik peran, pihak perusahaan juga harus waspada dengan stres kerja yang mungkin dialami oleh karyawan. Kondisi stres kerja merupakan suatu kondisi tegang yang dialami oleh karyawan atau seseorang disebabkan oleh keadaan yang mempengaruhi hal tersebut, dikenal sebagai stres (Juwita \& Arintika, 2018).

Berdasarkan tabel 2 diketahui bahwa responden paling banyak adalah mengalami stres sedang yaitu sebanyak 28 responden $(77,8 \%)$. Munculnya stres adalah akibat dari ketidakmampuan dari seorang individu dalam memenuhi harapan dan tuntutan terhadap dirinya, sedangkan menurut (Robbins \& Judge, 2015) stres adalah kondisi yang berubah-ubah yang menghadapkan seseorang pada tuntutan, sumber daya, atau suatu peluang yang berkaitan dengan apa yang diinginkan dengan hasilnya yang dirasa penting namun tidak pasti. Dari kedua definisi tersebut,dapat diambil kesimpulan definisi stres kerja adalah suatu tekanan yang dapat menyebabkankeadaan emosi, proses berfikir, dan kondisi dari seorang individu. Terdapat beberapa penyebab stres diantaranya: (a). Beban kerja yang berlebihan; (b) sikap dan tekanan dari pimpinan yang kurang adil dan wajar; (c) waktu dan peralatan yang mendukung kerja kurang memadaidan waktu yang terbatas; dan (d) konflik antara individu dengan pimpinan atau kelompok kerja. Sedangkan menurut (Robbins \& Judge, 2015) terdapat tiga sumber stres, yaitu: (a) faktor organisasi, meliputi: struktur organisasi, tuntutan tugas, peran, antar 
individu, kepemimpinan organisasi, dan perluasan organisasi.; (b) faktor individu, meliputi masalah : kepribadian individu, masalah keluarga, atau ekonomi; dan (c) faktor lingkungan, meliputi:ketidakpastian ekonomi, politik, dan teknologi.

Berdasarkan tabel 3 diketahui bahwa responden paling banyak adalah mengalami konflik peran ganda berpengaruh ke stres sedang yaitu sebanyak 28 responden (77,8\%). Merujuk hasil penelitian terdahulu, diperoleh hasil yang menunjukan pengaruh positif yang signifikan antara konflik peran dan stres kerja, konflik peran berkontribusi negatif dengan kepuasan dan stres kerja karyawan, serta stres kerja menjadi mediasi antara konflik peran dan kepuasan kerja (Iqbal, Iqbal, N., Khattak, M. A., and Quarat-Ul-Ain. 2013). Namun, penelitian lain menunjukkan hasil yang berbeda, karena konflik peran tidak berpengaruh pada stress kerja (Safaria, Othman, \& Wahab, 2011).

Hasil analisis didapatkan $\mathrm{p}$ value 0.001 dimana pada nilai $\alpha \leq 0.05$ dapat disimpulkan terdapat hubungan berarti antara konflik peran ganda dengan tingkat stres kerja di polres lampung utara 2018. Hasil penelitianini sejalan dengan temuan Juwita, K \& Arintika, D, (2018), yang dilakukan pada karyawan PT. Jombang Intermedia Pers menunjukkan adanya dampak konflik peran pada peningkatan stres kerja karyawan yang berarti apabila semakin sering terjadi konflik peran membuat stres kerja karyawan meningkat. Karyawan Radar Jombang sering mengerjakan beberapa tugas yang harus diselesaikan dalam waktu yang sama sehingga mengalami stres karena dirasa tidak begitu efektif dari sisi waktu dan tenaga. Bentuk stres yang dirasakan yaitu merasa kelelahan, tegang, mudah tersinggung dan bahkan dengan banyaknya pekerjaan yang harus diselesaikan membuat karyawan menyalahkan pekerjaan orang lain. Hasil penelitian ini memperkuat penelitian Iqbal pada tahun 2013 yang memberikan hasil bahwa adanya hubungan positif yang signifikan antara konflik peran dan stres kerja.
Menurut teori, konflik peran ganda merupakan masalah yang banyak memiliki kepentingan dalam manusia. Apabila kepentingan-kepentingan itu datang secara bersamaan maka akan menciptakan konflik (Wikipedia, 2018). Konflik dapat terjadi pada saat muncul dua kebutuhan atau lebih secara bersamaan. Berbagai tekanan-tekanan yang dialami dalam pekerjaan dan keluarga akan menimbulkan suatu peristiwa-peristiwa yang merupakan luapan dari emosi yaitu stres kerja (Rivai, 2014).

Penelitian yang dilakukan oleh Laksmi, Nimas Ayu Putri dan Cholichul Hadi (2012) dengan judul "hubungan antara konflik peran ganda dengan stres kerja pada karyawati bagian produksi Pt.X, menemukan bahwa dari hasil analisis data penelitian diperoleh nilai korelasi antara konflik peran ganda dengan stres kerja sebesar -0,274 dengan taraf signifikansi sebesar $0,045(\mathrm{p}<0,05)$. Hal ini menunjukkan bahwa terdapat korelasi yang signifikan antara konflik peran ganda dengan stres kerja pada karyawati bagian produksi PT.X. Koefisien korelasi yang bertanda negatif menunjukkan adanya korelasi negatif antara variabel. Artinya, semakin tinggi konflik peran ganda, maka stres kerja semakin tinggi pula. Begitu pula sebaliknya, semakin rendah konflik peran ganda, maka semakin rendah stres kerja.

Hasil ini juga sejalan dengan penelitian yang dilakukan oleh Desi Wulandari, D dan Dwiyanti, R (2014), dengan judul "hubungan antara konflik peran ganda dengan stres kerja pada perawat wanita yang sudah menikah" menemukan bahwa dari hasil penelitian diperoleh nilai korelasi antara konflik peran ganda dengan stres kerja sebesar 0,035 dengan taraf signifikansi sebesar 5\% (p < $0,05)$. Hal ini menunjukkan bahwa terdapat korelasi yang signifikan antara konflik peran ganda dengan stres kerja pada perawat wanita yang sudah menikah di RSUD Banyumas.

Wanita sebagai karyawan yang bekerja di bidang industri memiliki tekanan atau stres yang cukup tinggi karena harus mampu mencapai target yang ditentukan perusahaan tiap periodenya. Tidak hanya itu karyawan dituntut untuk mampu memberikan pelayanan yang terbaik bagi pelanggan 
sehingga mampu bersaing dengan industri sejenis lainnya. Belum lagi wanita memiliki tanggungjawab yang tinggi pula dalam hal mengurus keperluan rumah tangga. Sehingga dibutuhkan dedikasi yang tinggi bagi wanita untuk dapat membagi waktu dan perhatiannya bagi keluarga maupun bagi pekerjaannya sebagai karyawan. Hal ini memiliki kemungkinan yang cukup tinggi untuk menimbulkan adanya stres bagi wanita (Nahwi, 2017). Berdasarkan hasil penelitian dan temuan terdahulu dapat disimpulkan bahwa semakin tinggi konflik peran ganda yang terjadi maka akan semakin tinggi juga pengaruhnya pada tingkat stres kerja.

\section{KESIMPULAN}

Hasil penelitian menunjukkan adanya masalah tingginya konflik peran dan stress kerja pada tingkat yang sedang. Berdasarkan hasil penelitian dan temuan terdahulu dapat disimpulkan bahwa semakin tinggi konflik peran ganda yang terjadi maka akan semakin tinggi juga pengaruhnya pada tingkat stres kerja.

Peneliti menyarankan untuk tenaga kesehatan agar dapat melakukan edukasi terkait tentang peran kepada keluarga, serta edukasi tentang pencegahan dan pengendalian terhadap stres kerja yang nantinya dapat berpengaruh terhadap kemutuan kinerja. Lakukan rapat koordinasi guna membahas berbagai kendala yang dihadapi selama ini agar tidak terjadi konflik peran gandayang dapat menimbulkan stres kerja yang dapat menurunkan kinerja.

\section{DAFTAR PUSTAKA}

Abdulghani, HM et al., (2017). Stress and its effects on medical students: A crosssectional study at a college of medicine in Saudi Arabia. Journal of Health, Population and Nutrition, 516522.

Azwar, S, (1999), Penyusunan Skala Psikologi, Edisi ke 1, Yogyakarta: Pustaka Pelajar.
Gibson, 2005. Organisasi, prilaku dan struktur. Terjemahan. Jakarta. Erlangga

Hidayati, F., (2000), Psikologi Abnormal, Buku Ajar Fakultas Psikologi. Semarang:Universitas Diponegoro

Iqbal, N., Khattak, M. A., and Quarat-UlAin. (2013), "Impact of Role Conflict on Job Satisfaction, Mediating Role of Job Stress in Private Banking Sector", Interdisciplinary Journal of Contemporary Research Business, 711722.

Jeni, W, (2015), Tinjauan tentang Konflik Peran Ganda dan Dukungan Sosial Suami terhadap Stress Kerja, Jurnal Ecodemica: Jurnal Ekonomi, Manajemen, dan Bisnis, 417-437.

Juwita, K \& Arintika, D, (2018), Dampak Konflik Peran Terhadap Stres Dan Kepuasan Kerja Karyawan Pt. Jombang Intermedia Press (Jawa Pos Radar Jombang), Jurnal Manajemen Indonesia. 105-115.

Laksmi, Armi Riani, M. 2012. Perspektif Kompensasi. Surakarta: Yuma Pustaka

Magdalena. 2009. Efektivitas Organisasi (Kaidah Perilaku). Jakarta. LPPM dan Erlangga

Markutowati, D, Rahardjo, P, Setyawati, R. (2015), Konflik Peran Ganda Stres Kerja Pada Anggota Polisi Wanita (Polwan). Physico Idea. 74-85.

Nova \& Ispriyanti, Dwi, (2012), Analisis tingkat Stress wanita karir dalam peran gandanya, Media Statistika, Volume. 5, No. 1, Juni 2012.

Rini, J.F., (2002), Stress Kerja, Jakarta, Team e-psikologi.com, URL: http://dennyhendrata.wordpress.com/20 06/12/04/stress-kerja

Rivai V, Mulyadi D. (2014). Kepemimpinan dan perilaku organisasi. Jakarta: Rajawali pers

Robbins, \& Judge, (2015), Teori organisasi, struktur, desain, dan aplikasi. (Alih Bahasa: Tim Indeks). New Jersey: Prentice Hall

Safaria, T., bin Othman, A., \& Wahab, M. N. A. (2011). The Role of Leadership Practices on Job Stress among Malay Academic Staff: A Structural Equation 
Modeling Analysis. International Wulandari, D dan Dwiyanti, R. (2014). Education Studies, 4(1), 90-100.

Sherina MS, Rampal L, (2017). Buku ajar fundamentalkeperawatan: Konsep, Jurnal Hubungan Antara Konflik Peran Ganda Dengan Stres Kerja Pada proses, danPraktik. Jakarta Perawat Wanita Yang Sudah Menikah. Pshyco Idea. 33-41. 